\title{
The East-West Divide in the European Union: A Development Divide Reframed as a Political One
}

\author{
Alina Bârgăoanu, Raluca Buturoiu, and Flavia Durach
}

\section{A World in Flux}

This chapter focuses on the return of the East-West divide in the European Union, which is fuelled by persistent differences in the level of development of the Old (Western) Member States (OMS), and the New (CEE) Member States (NMS), and fuels the major geopolitical shifts shaking the current world order.

The world we live in is "a world in flux", as Verbeke (2017) aptly describes it, and the European Union does not appear to be in a position to evade this esprit du temps. Events of the past decade, such as the discussion about Grexit in the context of the Greek bailouts, the calls for burden sharing inside NATO, the Brexit referendum and its aftermath, the interruption of TTIP negotiations, the new foreign policy of the Trump administration and its drive towards bilateralism at the expense of multilateralism have signalled deep changes in the transatlantic world and the liberal order it embodies, with a major impact on the EU as one of the biggest beneficiaries of the post-WWII order.

What makes the European Union vulnerable to these contemporary developments (especially "America first" and the drive towards multilateralism) is, among other things, its increasing lack of cohesion and convergence. The euro crisis that started in 2007 brought about a pan-European desolidarisation and fragmentation both across and within member states. At first, the fault lines symbolically separated the

This chapter has been prepared with financial support granted in the project "State of the Nation. Designing an innovative instrument for evidence-based policy-making" (SIPOCA 11, MySMIS 118305), which is co-financed by the European Social Fund through the Operational Programme Administrative Capacity 2014-2020.

\footnotetext{
A. Bârgăoanu $(\varangle) \cdot$ R. Buturoiu $(\varangle) \cdot$ F. Durach $(\bowtie)$

flavia.durach@comunicare.ro

National University of Political Studies and Public Administration, Bucharest, Romania

e-mail: alina.bargaoanu@comunicare.ro; raluca.buturoiu@comunicare.ro; 
highly-performing, expert-oriented, fiscally disciplined North and the indebted, import-oriented and fiscally "exuberant" South. Over time, more and more divides have surfaced, such as elites vs citizens, euro vs non-euro, Schengen vs non-Schengen, arrival vs destination countries and Great Britain vs everybody else.

The refugee crisis and Brexit have brought about a new divide, which builds on the existing ones and amplifies them in a dramatic manner-the East-West divide. In our opinion, it is the most dramatic divide inside the European Union for several reasons. As we said, it builds on the previous divides and escalates them; it has acquired political overtones ("liberal" vs "illiberal"); it is "underwritten" by real development gaps, which can be overcome only in the long term; and it has a special geopolitical significance since it is a divide emerging at the Eastern frontier of the $\mathrm{EU}$, traditionally a crossroads of geopolitical interests. What appeared as a financial divide brought about by different fiscal policies is now morphing into a geopolitical crisis of the EU.

\section{The Eastward Enlargement: A Transition from One International Regime to Another}

The eastward enlargement meant the largest expansion of the EU in terms of territory, number of states and population. Apart from the initial enthusiasm and the obsessive, highly ideological discourse focused on the "export of Western norms and values to the former communist countries", what created the greatest challenge was the attempt to close the economic/development gaps between the Western and the Eastern part of the EU. Around the time of accession of the new Eastern members, some scholars warned against a greater heterogeneity of the EU, making room for conflicts over diverging different national policy objectives, economic structures and potentials, financial constraints and societal preferences (Ahrens et al. 2005; Krätke 2002).

Enlargement was described as following an "imperial pattern" (Zielonka 2006, 2008). Instead of replicating the traditional Westphalian nation-state model on a larger scale, Zielonka $(2006,2008)$ argues that the EU acts as a neo-medieval empire, with a meta-governor (the central EU institutions) and accommodates changing borders and diversity. In a sense, Eastern Europe experienced a transition not from authoritarian communist regimes to democracy but from one international regime to another (Janos 2001). The new order entrenched in the enlargement policy reflected the interests and identity of the new hegemon: security in the Eastern vicinity, a need to pre-empt political chaos, the need to demonstrate the universal relevance of liberal projects (Janos 2001).

The discussion about the patterns of EU integration in CEE countries is further confounded by the fact that there are persistent asymmetries in the relations between the Western and Eastern parts of the European Union (Epstein and Jacoby 2014). The less-than-favourable attitudes of Western Europe towards CEE states precede 
the moment of enlargement, the fall of communism and even the Cold War. "In some sense, the forsaking of ECE following World War II came naturally for West European and American leaders, many of whom viewed the East as politically, economically and culturally distinct-and importantly, inferior" (Epstein and Jacoby 2014, p. 3).

These patterns are painfully obvious in the recent conflict between Brussels and Poland (the "poster child of EU integration" until not long ago). It is the particular choice of words that reveals the East-West divide: innuendos on Poland's unwillingness to solve the issue by means of dialogue (Austrian Federal Minister Gernot Blümel); a power-asymmetry implied when Poland is expected to "provide explanations" (Commission vice-president Frans Timmermans), like a scolded child; the Swedish minister arguing that the issue of rule of law is about the credibility of the entire EU. Poland alludes to discrimination: "We would like member states to approach the Polish evaluation of justice reforms with the same attention, trust and impartiality" (head of Polish diplomacy, Konrad Szymański). Thirteen or ten years, respectively, after the historic reunification of Europe through EU enlargement (2004, 2007), the sources of discontent between the newcomers and the established members are neither few nor easy to solve.

Why was it so easy for the East-West divide to return? In our view, the main reason is that the two halves of the EU function in rather different socio-economic realities, leading, in turn, to different expectations regarding European integration. For the remainder of this chapter, we will analyse the East-West divide from the perspective of development gaps, arguing that while this divide has political, historical and even perceptual overtones, its main driver is developmental, being socio-economic in nature.

It is beyond doubt that NMS were able to take advantage of the many benefits created by EU enlargement: securing high volumes of foreign investment (FDI), access to markets, GDP increase, greater prosperity, modernisation of the service sector, improvements in human capital, and modernisation of part of their infrastructure. At the same time, this new openness to liberal/Western capital has brought about new challenges: vulnerability to external economic shocks (Medve-Bálint 2014), diminished capacity for autonomous innovation and efficiency of the domestic firms (Epstein 2014) and a huge displacement of the working population to the richer parts of the EU (as experienced especially by Romania and Poland).

Despite undisputable economic progress-for example, catching-up in terms of GDP per capita, as noted by Goedemé and Collado (2016)_NMS have been lagging behind in social issues such as minimum wage, expenditures on social protection, life satisfaction, poverty, deprivation, income inequality, unemployment, and mortality (Aidukaite 2011). Furthermore, the NMS of CEE and Baltic countries have the highest levels of aggregate risk of chronic relative material deprivation while Northern and Continental European countries have the lowest levels (Gábos and Goedemé 2016).

Another limitation worth discussing in relation to CEE membership to the EU is that the supranational organism is poor in its provision for distribution of wealth and 
prosperity - both across the EU and within member states. With respect to convergence between member states, macroeconomic data suggest that, while the EU's "convergence machine" turned many low-income and middle-income countries into high-income economies, the 2009 economic crisis turned convergence into divergence. Income differences between the EU-15 and the NMS remain substantial. The national median income of many EU-15 countries is relatively close to the EU-wide median income, whereas the median income in the NMS is generally substantially lower than the EU-wide median income (Goedemé and Collado 2016). As far as intra-national convergence is concerned, while many regions in CEE countries are likely to slowly catch up with their Western neighbours, they leave others behind in relative poverty in the process (Bosker 2009).

\section{The East-West Divide in Data}

Our research investigates the return of the East-West divide in the EU from the perspective of development and progress. Our research is premised on the idea that the main driver of this divide is the socio-economic one and it seeks to show that CEE membership to the EU has left largely untouched development indicators such as the urban-rural ratio, level of capitalisation and savings, entrepreneurship and innovation, integration in global/European production, technology, $R \& D$ chains, the minimum wage, social expenditures, poverty, deprivation, income inequality, unemployment, and mortality.

Our research will underline the morphology of the East-West "development divide" by focusing on its socio-economic determinants. We will use institutional data sources such as Eurostat, the World Bank, and the United Nations and we will apply secondary data analysis to compare and discuss the development patterns in OMS and NMS. Specifically, our objective is to identify the differences in development based on the following interconnected (a) economic indicators: real GDP per capita, GDP per capita in Purchasing Power Standards (PPS), final consumption expenditure as a percentage of GDP, net national income, minimum wages, foreign direct investments, and (b) social indicators: migration by country of origin, life expectancy at birth, healthy life years at birth, healthy life years at the age of 65, human development index, and the world happiness report. This part of the research will seek to clarify that, in NMS and elsewhere, economic growth is not an interchangeable word for development, which is simultaneously an economic, social, political, and cultural phenomenon (Goldin 2016).

The timeframe for this empirical research is 1990-2018, covering several milestones: the fall of the communist regime in Central and Eastern European countries, the completion of the eastward enlargement, the euro crisis, the Ukraine crisis, the refugee crisis, and Brexit. The timeframe also depends on data availability at the time of writing this chapter. Throughout our chapter, we define the OMS as the founding members, plus the countries from the first, second and third enlargement waves, plus two Mediterranean countries which joined the EU in 2004 (i.e., Germany, France, 
Italy, Luxembourg, The Netherlands, Belgium, Denmark, the UK, Ireland, Greece, Spain, Portugal, Austria, Finland, Sweden, Cyprus, and Malta); all also referred to as the EU's Western part. By contrast, the NMS are referred to as the countries that joined the EU in 2004, 2007 and 2013 - predominantly former communist countries from the EU's Eastern periphery (i.e., the Czech Republic, Estonia, Hungary, Latvia, Lithuania, Poland, Slovakia Slovenia, Romania, Bulgaria, and Croatia). We chose to create these two clusters because they reflect, both pragmatically and symbolically, the East-West divide that is the focus of this research.

\subsection{Economic Development Patterns}

One indicator revealing how well off a country is, and thus explaining a country's level of development, is real GDP per capita. The indicator is calculated as the ratio of real GDP to the average population of a specific year, meaning that it measures the average real income specific to a country. Figure 1 shows the average of real GDP per capita by comparatively analysing the trends of real GDP averages in NMS and OMS.

Data reveal that there is an obvious economic development gap between the NMS and the OMS. The difference in the average of real GDP per capita between NMS and OMS is consistent over time, despite European integration. In 2016, the average value of GDP per capita in NMS $(12,136 € /$ capita) was around third times lower than that in OMS (34,835 €/capita). Ironically enough, the economic benefits of EU membership seem to be rather meagre. Although the EU structural and cohesion funds were highly available starting from 2007, and the NMS succeeded in contracting them (for an overview, see the KPMG report 2016), the economic performance of these countries did not seem to significantly improve over time.

In order to get a better image about cross-country economic performances, one should look at the volume index of GDP per capita in PPS. The indicator is expressed in relation to the European Union (EU28) average set to equal 100. If the index of a country is higher than 100, that country's level of GDP per capita is higher than the EU

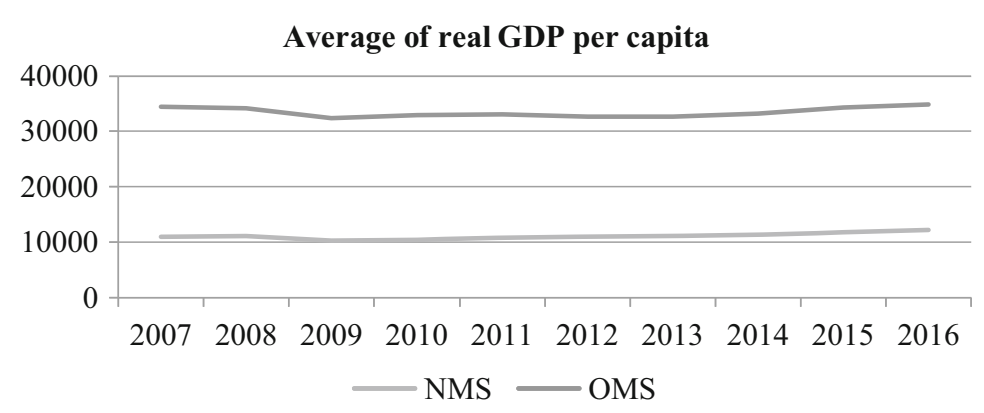

Fig. 1 Average of real GDP per capita in NMS and OMS. Source: Eurostat, variable tsdec100. Retrieved from: https://ec.europa.eu/eurostat/web/products-datasets/-/tsdec100, accessed April 10th, 2018 
average and vice versa. Data for 2016 show that there is a clear divide between OMS and NMS in terms of GDP per capita in PPS (Eurostat, variable tec00114, accessed 2018). OMS register values significantly higher than the EU28 average (100), while NMS register lower values. Broadly, the top part of the ranking consists of OMS while the bottom part is dominated by NMS. Specifically, the top five EU countries in terms of GDP per capita in PPS are Luxembourg (258), Ireland (183), The Netherlands (128), Austria (128), and Denmark (124), whereas the last ranked five countries are Bulgaria (49), Romania (58), Croatia (60), Latvia (65), and Hungary (67). We can notice that there is a huge difference of performance across countries-Bulgaria has an index of GDP per capita in PPS five times lower than Luxembourg's.

At first glance, a consumption boom can be considered a measure of well-being and progress for the CEE member states. What we find worrying is that consumption levels in the NMS are similar to those in the advanced economies while income levels are significantly lower. Citizens in NMS make efforts to improve their way of living to meet Western standards by collecting debt or by cutting down on savings. To analyse this trend, we turned to the indicator "final consumption expenditure as percentage of GDP" (Eurostat, variable nama_10_gdp, accessed 2018). Final consumption expenditure is expenditure by resident institutional units-including households and enterprises whose main economic centre of interest is in that economic territory-on goods or services that are used for the direct satisfaction of individual needs or wants or the collective needs of members of the community. In 2016, consumption levels in NMS were similar to those in OMS while having significantly lower income levels. For example, the top five NMS in terms of final consumption expenditure as percentage of GDP-Lithuania (81.5\%), Latvia (79.5\%), Croatia (77\%), Romania (76.9\%) and Bulgaria (76.55\%)—have consumption levels similar to OMS whose net national incomes and GDP levels are considerably higher-for example, Italy $(79.6 \%)$ and Finland $(79.1 \%)$ (Eurostat, variables tsdec230 and nama_10_gdp, accessed 2018). This pattern in consumption expenditure is a measure suggestive of the centre-periphery relations in which the latter tries to mimic the standard of living, level of progress and innovation of the centre without actually managing to catch up in terms of economic performances.

Another important indicator of economic development is the monthly minimum wages $^{1}$ in PPS and in euro (Eurostat, variable earn_mw_cur, accessed 2018). Figure 2 shows the average of minimum wages, as of 1 January 2018, in PPs and in euro, by comparing NMS with OMS.

Data show a significant gap between the average value of minimum wages in NMS and OMS. Bulgaria registers the lowest value of minimum wage as of 1 January 2018 (261 €), followed by nine other NMS, also located in Central and Eastern part of the EU, which register minimum wage values between $400 €$ and $500 €$. On the other side, there are the old EU countries where the value of the minimum wage is much higher. For example, in Luxembourg, Ireland, The

\footnotetext{
${ }^{1}$ Twenty-two out of the 28 Member States of the European Union have national minimum wages. Only Denmark, Italy, Cyprus, Austria, Finland, and Sweden do not.
} 
Average of minimum wages - as of 1 January 2018, in PPS and in euro

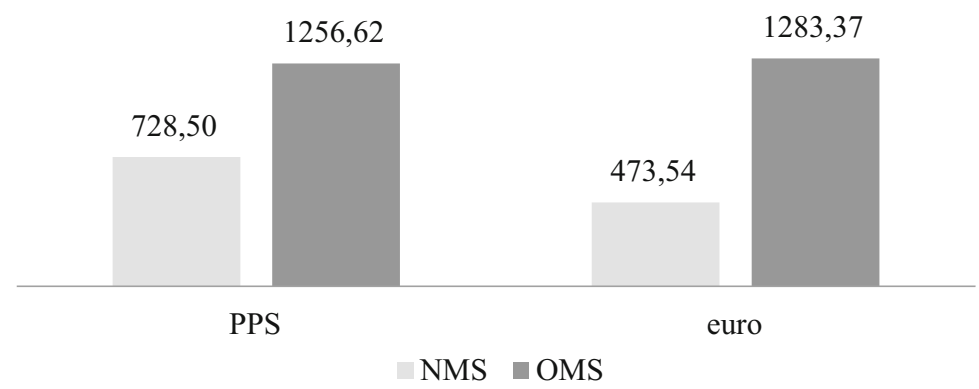

Fig. 2 Average of minimum wages, as of 1 January 2018, in PPS and in euro in NMS and OMS. Source: Eurostat, variable earn_mw_cur. Retrieved from: http://appsso.eurostat.ec.europa.eu/nui/ show.do?dataset=earn_mw_cur\&lang=en, accessed February 15th, 2018

Netherlands, and Belgium, the minimum wage values vary between $1500 €$ and $2000 €$. Therefore, we can notice major disparities between the NMS and OMS; the average value of minimum wages is around $500 €$ in NMS and almost three times higher in OMS (1300€). The situation is more dramatic if we take into consideration that the lowest minimum wage (Bulgaria, $261 €$ ) is almost eight times lower than the highest (Luxembourg, $1999 €$ ). When price level differences are eliminated, the divide seems to be attenuated - the average value of minimum wages in PPS is almost two times lower in NMS than in OMS (729 PPS in NMS and 1257 PPS in OMS). By eliminating price differences, minimum wages range from 546 PPS per month in Bulgaria to 1597 PPS in Luxembourg, meaning that the highest minimum wage is almost three times higher than the lowest; thus revealing a smaller gap.

The minimum wage, whose purpose is to protect employees from excessively low pay, is one way to ensure a more equitable share of the revenues and a means to overcome poverty and inequality. The aforementioned differences in minimum wages between OMS and NMS are a sign of divergence. As data suggest, while the minimum wage enforces a minimal standard of remuneration, its value largely depends on where in the EU the worker is based. This reinforces the East-West discrepancies, especially for vulnerable socio-demographic categories such as manual labourers and low-skilled workers living on minimum wages and is, in turn, linked to the economic migration fluxes from Eastern to Western countries.

In order to get a thorough understanding of the economic development gap between NMS and OMS, we will discuss foreign direct investments (FDI). If in other indicators, such as real GDP per capita and minimum wages, there is a clear divide between OMS and NMS in terms of achievements, FDI results suggest the attractiveness of CEE states for foreign investors. NMS manage to outperform some OMS as far as FDIs are concerned, as we will elaborate below. Data from 2016 show that some OMS (Luxembourg-45.81\%, Ireland-25.97\%, Malta-22.17\%, The Netherlands-19.81\%, Cyprus-13.01\%, and United Kingdom-11.07\%) register 
significantly higher values of foreign direct investment as a percentage of GDP than NMS (foreign direct investment, net inflows (\% of GDP), World Bank, variable BX. KLT.DINV.WD.GD.ZS, accessed 2018). According to the 2017 World Investment Report, the UK and The Netherlands are among the top five host economies in the world (together with the United States, Canada and Australia) in terms of FDI flows. In general, top countries attracting foreign investment are mainly situated in the OMS cluster. We notice as an exception the situation of Hungary, ranking first in 2016 in terms of highest foreign direct investment (54.6\%), mainly due to the support of the Hungarian Investment Promotion Agency (HIPA) ${ }^{2}$. Generally, NMS register values between $2.2 \%$ and $4 \%$, thus outweighing OMS such as Denmark (2.09\%), Greece $(1.59 \%)$, Germany $(1.51 \%)$, France $(1.43 \%)$, Italy $(0.99 \%)$, Finland $\left(-4 \%{ }^{3}\right)$ and Austria $(-7.66 \%)$ in terms of foreign direct investment in 2016.

Nevertheless, high levels of foreign direct investment in NMS countries do not seem to have led to indirect long-term benefits. While direct effects-upgrades in receiving foreign capital - are visible for NMS, indirect effects-including increasing competitiveness and the development of nationally-based companies that could compete with foreign-owned ones-are still flimsy. As Epstein (2014, p. 25) argues, "Indirect effects are arguably more important for the question of backwardness, since they affect a recipient country's capacity to develop autonomous innovation". In more general terms, the overall benefits did not transpose into higher levels of social equity and hence did not really contribute to lower levels of inequality; overall performances registered by NMS are still modest in comparison with those from OMS. Furthermore, as shown in previous sections, local firms are unable to compete with multi-national ones since they did not build the pathways for research and development, innovation, and human capital improvement. Excessive reliance on foreign capital damages a country's development by maintaining a dependency on an external "centre".

Data stemming from the economic development indicators we considered confirm the sources of what Janos (2000) called the "economic backwardness" of CEE. Here, multiple issues overlap, from the inability to take full advantage of foreign investments to lagging behind in terms of GDP or in the capacity of the economy to support a certain level of minimum wage without increasing unemployment or bankruptcies.

Furthermore, there is a subtler hierarchy (or development gap) inside NMS as well, a multi-tier pattern which is becoming more evident as one travels from Western Europe to the Czech Republic and Poland, and then further east and south. In other words, the development divide is not only between the OMS and

\footnotetext{
${ }^{2}$ For more details, see Hungarian Investment Promotion Agency (2017). Retrieved from: https:// hipa.hu/foreign-investors-continue-to-trust-in-hungary, accessed February 27, 2018.

${ }^{3}$ According to Eurostat, 2017, negative FDI values indicate where outflows of investment exceed inflows. This may indicate, for example, disinvestment, or reinvestment outside the country, discharges of liabilities, advance and redemption of inter-company loans, short-term credit movements, company dividends exceeding recorded income over a given period, or company operations being at a loss.
} 
NMS but also within the NMS cluster. For example, in 2016, Slovenia (18,500 €/ capita) and the Czech Republic (16,500 €/capita) had a real GDP per capita almost three times higher than Bulgaria (6000 €/capita) and over two times higher than Romania (7700 €/capita). In terms of minimum wages in euros on 1 January 2018, we can notice that in Slovenia ( $843 €$ ) the minimum wage is the highest among the NMS, this value being over three times higher than that in Bulgaria (261 €) and around two times higher than that in Lithuania (400€), Romania (408€) and Latvia (430 €). One explanation for this intra-NMS divide could be that the proximity to the core of Northwest Europe facilitated the accession and use of technological innovation and, therefore, reduced the vulnerabilities of backwardness experienced by South-Eastern European countries (Epstein 2014). Our view is also supported by the findings of the project The State of the Nation. The development of an innovative instrument for grounding the development of public policies in Romania, which relies on evidence-based comparisons within Romania's peer group (other CEE countries) in order to signal regional similarities and certain development patterns as a result of EU membership. ${ }^{4}$

\subsection{Social Development Patterns}

This section of our contribution is dedicated to social development indicators. By far, one of the most significant indicators explaining the development gap between OMS and NMS is the number of migrants. Figure 3 shows the total number of migrants by countries of origin by comparatively analysing migration stock across EU countries.

It is observable from the chart that soon after the fall of the communist regimes in Eastern Europe (1990), the European migratory routes were mainly from OMS to other OMS. Not surprisingly, migrants chose to establish in other OMS in order to feel at home in a place similar to their own in terms of economic development. In 1990, there was insignificant migration from OMS to NMS and between countries in the CEE cluster. Fifteen years later, after the successive waves of eastward enlargement, the patterns are completely different. The number of people moving from OMS to similar countries from OMS decreased to around 2 million (from 9,826,714 in 1990 to 7,667,937 in 2015). Instead, citizens from NMS prefer to move to OMS; in 2015, almost 9 million people from NMS moved to OMS (six times more than in 1990). The freedom of movement and residence for persons in the EU, which is the cornerstone of Union citizenship, established by the Treaty of Maastricht in 1992, made it possible for citizens from CEE to move to the more attractive EU-15 states (OMS).

\footnotetext{
${ }^{4}$ For further details, see the official webpage of the Project The State of the Nation. The development of an innovative instrument for grounding the development of public policies in Romania: http:// starea-natiunii.ro/en/, accessed March 8th, 2017.
} 
Total number of migrants by countries of origin comparison 1990-2015

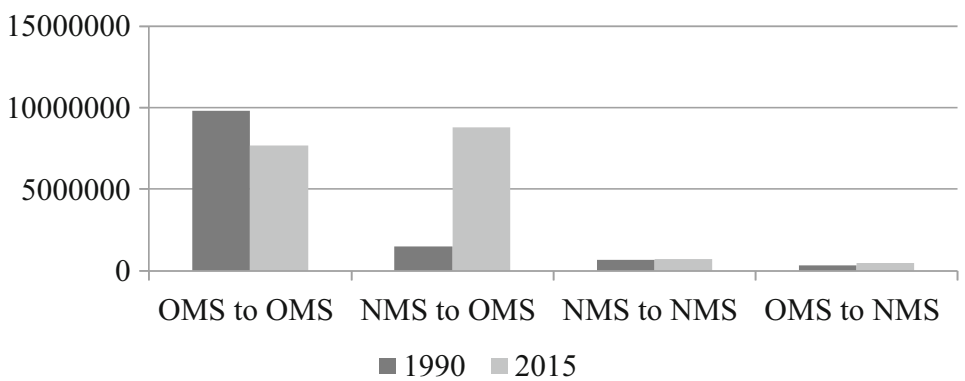

Fig. 3 Total number of migrants by countries of origin-comparison 1990-2015. Source: United Nations, Department of Economic and Social Affairs (2015). Trends in International Migrant Stock: Migrants by Destination and Origin (United Nations database, POP/DB/MIG/Stock/Rev.2015). Retrieved from: http://www.un.org/en/development/desa/population/migration/data/estimates2/esti mates15.shtml, accessed March 8th, 2018

Data show that, in general, NMS are not a favourite destination for people living in NMS or for those living in OMS. One explanation is income disparity, one of the main factors contributing to socio-economic inequality-for an overview, see the data explained above on minimum wages. Another explanation is that people are seeking stable, prosperous economies to work and live in (with high rates of GDP per capita and low unemployment rates). Hence, OMS seem the best choice.

The data are worrying, mainly because the movement of these high numbers of people from NMS to OMS entails long-term effects. Pensions, which take up about half of social spending in Eastern European countries, are the biggest worry. An article in The Economist (2017) reveals that in 2013, Latvia had 3.3 working-age adults for each person older than 65-a similar number to Britain and France. By 2030 that number is estimated to fall to just over two, a level that the UK and France will not reach until 2060.

NMS are not only lagging behind in economic terms but also concerning health and life expectancy. Life expectancy at birth represents the mean number of years that a person can expect to live if subjected to current mortality conditions throughout the rest of his or her life. Healthy life years (also called disability-free life expectancy) measure the number of remaining years that a person of a certain age should live without disability. It is a solid indicator to monitor health as a productivity/economic factor, being used to distinguish between years of life free of any activity limitation and years with at least one activity limitation. The emphasis is not exclusively on the length of life, as is the case for life expectancy, but also on the quality of life.

In general, data show that indicators related to life expectancy at birth have been on the increase during the past decade. For example, life expectancy at birth in the EU-28 increased by 2.9 years, from 77.7 to 80.6 years; the increase was 2.4 years for women and 3.4 years for men (Eurostat, variable demo_mlexpec, accessed 2018). 
This increase is due to a number of factors, including a reduction in infant mortality, rising living standards, improved lifestyles, and better education as well as advances in healthcare and medicine. However, data on healthy life years at birth (Eurostat, variable hlth_hlye, accessed 2018) are not so optimistic. Rather, the countries where healthy life years at birth increased during the last decade are exceptions. Therefore, we notice that even though life expectancy at birth increased, the number of years a person lives in good health remained similar or, even worse, decreased. Figure 4 shows a comparison between OMS and NMS in terms of life expectancy at birth and healthy life years at birth according to gender.

Data reveal that in OMS both life expectancy at birth and healthy life years at birth register higher values than in NMS. Life expectancy at birth for females is 3.5 years higher in OMS than in NMS, and for males it is 6.4 years higher in OMS than in NMS. While registering significantly lower values, healthy life years at birth registers similar differences (in years) when comparing OMS with NMS. These data, coupled with projection data on retirement age ${ }^{5}$ showing that the average age of retirement will be around $68-70$ years by 2050 , are worrying. These projections take into account the increase in life expectancy at birth and the old-age dependency while ignoring data on healthy life years at birth. In several cases, the retirement age is significantly higher than the average value of healthy life years at birth, especially for men. Even more alarming is the data on healthy life years at the age of 65 (Eurostat, variable hlth_hlye, accessed 2018). While people from OMS expect to live around ten more years in good health after the age of 65, those from NMS expect to live only around six more years.

\section{Life expectancy at birth vs. Healthy life years in absolute value at birth - data for 2015}

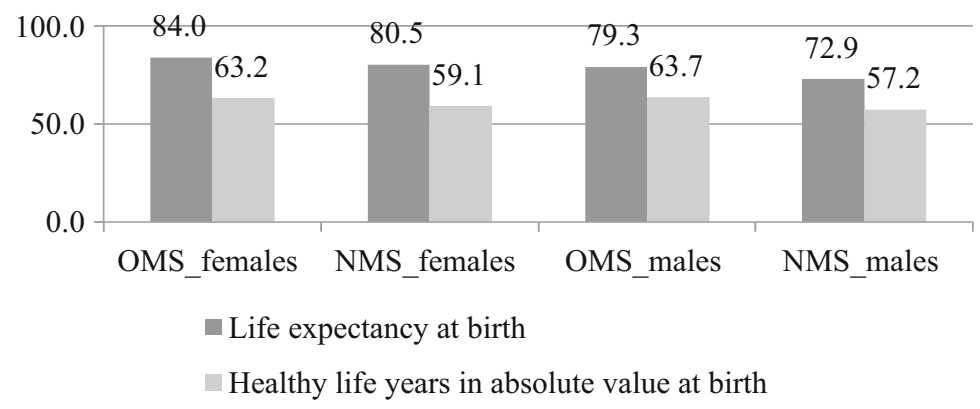

Fig. 4 Average of life expectancy at birth vs. Healthy life years in absolute value at birth according to gender-data for 2015. Source: Eurostat, variables demo_mlexpec and hlth_hlye. Retrieved from: http://appsso.eurostat.ec.europa.eu/nui/show.do?dataset=demo_mlexpec\&lang $=$ en, and http://appsso.eurostat.ec.europa.eu/nui/show.do?dataset=hlth_hlye\&lang=en, accessed March 8th, 2018

\footnotetext{
${ }^{5}$ For details, see Finnish Center for Pensions https://www.etk.fi/en/the-pension-system-2/the-pen sion-system/international-comparison/retirement-ages/, accessed February 28th, 2018.
} 
These data could be linked to other interesting statistics on the human development index, particularly created to emphasise that people and their capabilities should be the ultimate criteria for assessing the development of a country rather than economic growth alone. The human development index (HDI) is a summary measure of average achievement in key dimensions of human development: a long and healthy life, being knowledgeable, and having a decent standard of living. In terms of HDI, 1990-2015, accessed 2018), data show that there were no significant differences between the average values of HDI in OMS and in NMS. However, data for 2015 reveal that four countries from the old EU member states are in the top ten highest ranked on HDI (very high human development): Germany (4), Denmark (5), The Netherlands (7), and Ireland (8). All the other EU countries, except Bulgaria (which ranks high on human development), are ranked as having very high human development. Despite this ranking, the divide between OMS and NMS on the other key indicators of human development is starkly visible.

\section{The East-West Divide: Consequences for the Future of the EU}

While eastward enlargement was framed as a great victory for the EU's model of development, it actually failed to reduce the disparities between OMS and NMS. More than 10 years after accession, the socio-economic differences between the Western and the Eastern states of the EU are problematic, enduring realities.

The re-emergence of the East-West divide in the EU, in even starker terms than those at the height of the Cold War, is a worrisome phenomenon. Our research was premised on the idea that the major driver of the East-West divide is that of development and sought to draw attention to the socio-economic development indicators that have been left untouched, in some situations even aggravated, by the process of European integration. We consider that a sober, critical, evidencebased acknowledgement of the European Union's failure to make significant contributions to close this development divide is worth our attention. In our view, the success or failure of the project of European integration needs to be discussed in economic terms since prosperity - shared prosperity - was the foundational value of the EU: peace and prosperity, peace as a result of prosperity to be more specific. Given its developmental, socio-economic nature, this divide is difficult to overcome since the results of major developmental, transformative projects are difficult to achieve in the short term. Besides, the EU appears to have had no such large pan-European transformative projects in hindsight.

To further confound the problem, this development divide is reframed as a political divide ("liberal" vs. "illiberal") or a civilisational one (the "cultural backwardness" of the East vs. the "moral superiority" of the West), a fact that obliterates its root causes. Besides, we are dealing with a geopolitically sensitive area, a crossroads of major geopolitical interests and trends, and the consequences of this 
socio-economic development divide, reframed as a political or even a civilisational divide, are felt in the geopolitical strategic field.

The temptation to reframe this development gap in political, cultural, or even civilisational terms is big; just as equally big appears to be the temptation to leave CEE behind and consider the eastward enlargement a geopolitical blunder. No matter how alluring this scenario might be for some short-sighted leaders, leaving CEE behind, in practical as well as in symbolic terms, may well create the greatest vulnerability for the EU and the international liberal order in the following years.

\section{References}

Ahrens, J., Hoen, H. W., \& Ohr, R. (2005). Deepening integration in an enlarged EU: A clubtheoretical perspective. Journal of European Integration, 27(4), 417-439.

Aidukaite, J. (2011). Welfare reforms and socio-economic trends in the 10 new EU member states of Central and Eastern Europe. Communist and Post-Communist Studies, 44(3), 211-219.

Bosker, M. (2009). The spatial evolution of regional GDP disparities in the "old" and the "new" Europe. Papers in Regional Science, 88(1), 3-27.

The Economist. (2017). Eastern Europe's workers are emigrating, but its pensioners are staying. Retrieved February 27, 2018, from https://www.economist.com/news/europe/21714999-eusnewest-members-face-economic-decline-unless-they-woo-back-workers-or-recruit-immigrants

Epstein, R. A. (2014). Overcoming 'Economic Backwardness' in the European Union. Journal of Common Market Studies, 52(1), 17-34.

Epstein, R. A., \& Jacoby, W. (2014). Eastern enlargement ten years on: Transcending the EastWest divide? Journal of Common Market Studies, 52(1), 1-16.

Finnish Center for Pensions. Retrieved February 28, 2018., from https://www.etk.fi/en/the-pensionsystem-2/the-pension-system/international-comparison/retirement-ages/

Goedemé, T., \& Collado, D. (2016). The EU convergence machine at work. To the benefit of the EU's poorest citizens? Journal of Common Market Studies, 54(5), 1142-1158.

Goldin, I. (2016). The pursuit of development: Economic growth, social change, and ideas. Oxford: Oxford University Press.

Gábos, A., \& Goedemé, T. (2016). The Europe 2020 Social Inclusion Indicators: Main conclusions of the ImPRovE project on validity, methodological robustness and interrelationships (No. 16/13). Herman Deleeck Centre for Social Policy, University of Antwerp.

Hungarian Investment Promotion Agency. (2017). Foreign investors continue to trust in Hungary. Retrieved February 27, 2018, from https://hipa.hu/foreign-investors-continue-to-trust-inhungary

Janos, A. C. (2000). East Central Europe in the modern world: The politics of the borderlands from pre- to postcommunism. Stanford, CA: Stanford University Press.

Janos, A. C. (2001). From Eastern empire to Western hegemony: East Central Europe under two international regimes. East European Politics and Societies, 15(2), 221-249.

KPMG Report. (2016). EU funds in Central and Eastern Europe. Progress Report 2007-2015. Retrieved February 27, 2018, from https:/assets.kpmg.com/content/dam/kpmg/pdf/2016/06/ EU-Funds-in-Central-and-Eastern-Europe.pdf

Krätke, S. (2002). The regional impact of EU Eastern enlargement: A view from Germany. European Planning Studies, 10(5), 651-664.

Medve-Bálint, G. (2014). The role of the EU in shaping FDI flows to East Central Europe. Journal of Common Market Studies, 52(1), 35-51.

United Nations World Investment Report. (2017). Investment and the digital economy. Retrieved February 28, 2018, from http://unctad.org/en/PublicationsLibrary/wir2017_en.pdf 
Verbeke, J. (2017). A world in flux. EGMONT Royal Institute for International Relation. Security Policy Brief, No 02, November 2017. Retrieved February 28, 2018, from http://www. egmontinstitute.be/content/uploads/2017/11/SPB92-Verbeke.pdf?type $=$ pdf

Zielonka, J. (2006). Europe as empire: The nature of the enlarged European Union. Oxford: Oxford University Press.

Zielonka, J. (2008). Europe as a global actor: Empire by example? International Affairs, 84(3), 471-484.

Open Access This chapter is licensed under the terms of the Creative Commons Attribution 4.0 International License (http://creativecommons.org/licenses/by/4.0/), which permits use, sharing, adaptation, distribution and reproduction in any medium or format, as long as you give appropriate credit to the original author(s) and the source, provide a link to the Creative Commons licence and indicate if changes were made.

The images or other third party material in this chapter are included in the chapter's Creative Commons licence, unless indicated otherwise in a credit line to the material. If material is not included in the chapter's Creative Commons licence and your intended use is not permitted by statutory regulation or exceeds the permitted use, you will need to obtain permission directly from the copyright holder. 